\title{
The effects of different amounts and types of fat on the level of conjugated linoleic acid in the meat and milk of sheep*
}

\author{
M. Szumacher-Strabel ${ }^{1}$, A. Potkański ${ }^{1}$, A. Cieślak ${ }^{1}$, \\ J. Kowalezyk ${ }^{2}$ and M. Czauderna ${ }^{2}$ \\ 'Department of Animal Nutrition and Feed Management, \\ August Cieszkowski Agricultural University \\ Wolyńska 33, 60-637 Poznań, Poland \\ ${ }^{2}$ The Kielanowski Institute of Animal Physiology and Nutrition, \\ Polish Academy of Sciences \\ 05-11- Jablonna, Poland
}

\begin{abstract}
The influence of the addition of rape seed oil, linseed oil and hydrogenated rape seed oil to the diet for milking ewes and growing lambs on the concentration of cis-9, trans-11 octadecadienoic acid, a conjugated linoleic acid, in milk and meat was investigated. In Experiment 1, 24 fattened lambs of $22 \pm 2 \mathrm{~kg}$ body weight were divided into four groups and fed control (without added fat) and experimental diets with the respective additions to the basic diet of $6 \%$ rape seed oil, linseed oil or hydrogenated rape seed oil. In experiment 2 four lactating ewes of $50 \pm 5 \mathrm{~kg}$ body weight were fed a basic diet for milking sheep consisting of $60 \%$ concentrate and $40 \%$ meadow hay (control group), which was supplied with 4,8 or $10 \%$ of fat in dry matter for the experimental groups. Supplementing diets for fattened lambs with $6 \%$ rape seed oil, linseed oil or hydrogenated rape seed oil had no effect on the CLA content in meat. Rape seed oil and hydrogenated rapeseed oil had no effect on the CLA content in milk, whereas the addition of linseed oil significantly increased $(P<0.05)$ the CLA level in milk.
\end{abstract}

KEY WORDS: sheep, fat, conjugated linoleic acid, CLA

\section{INTRODUCTION}

Conjugated linoleic acids (CLA) found in ruminant milk and meat are a byproduct of incomplete biohydrogenation of lipids by ruminal bacteria (Chouinard

* Supported by the State Committee for Scientific Rescarch, Grant No. 5 PO6E 01119 
et al., 2001). CLA refers to a mixture of positional and geometric isomers of octadecadienoic (linoleic) acid with conjugated double bonds (Ip et al., 1994). The most extensively investigated CLA isomer is cis-9, trans-11 octadecadienoic acid, which is thought to be the biologically active form. Conjugated linoleic acid is unusual among anti-carcinogenic compounds in that it acts to both reduce the incidence of tumors in laboratory animal models and is a cytotoxic agent to existing tumor cells. Meat from ruminants generally contains more CLA that meat from nonruminants (Ip, 1994; Bessa et al., 2000). In addition to meat, milk and other dairy products are good sources of CLA (Ip, 1994; Parodi, 1994). Because fat is commonly used to supply energy in the diets of high producing ruminants, it is necessary to determine which fat sources yield the most CLA in the rumen as well as in milk and meat fat. Because there is no evidence for conversion of 9-cis, 12-cis-octadecadienate to CLA (via an isomerase) in humans (Adlof et al., 2000), research needs to focus on maximizing CLA formation in animal products (i.e., from ruminants) that are consumed by humans. Therefore, the objective of this study was to determine the effect of three fats on CLA formation in sheep milk and meat.

\section{MATERIAL AND METHODS}

\section{Experiment 1}

Twenty-four fattened lambs of $22 \pm 2 \mathrm{~kg}$ body weight were divided into four groups and fed ad libitum a diet consisting of concentrate and meadow hay without added fat for the control group and with the addition of $6 \%$ of rape seed oil, hydrogenated rape seed oil or linseed oil in dry matter to the concentrate for the experimental groups. Lambs were fattened until $40 \mathrm{~kg}$. The composition of diets is shown in Table 1. Drinking water was available ad libitum. Consequently, special emphasis was placed on the effect of dietary fat on conjugated linoleic acid levels in the muscles of lambs.

TABLE 1

Composition of the concentrate fed to lambs (Experiment 1), \%

\begin{tabular}{lcc}
\hline \multirow{2}{*}{ Components } & \multicolumn{2}{c}{ Level of fat rapeseed oil, linseed oil or hydrogenated rapeseed oil } \\
\cline { 2 - 3 } & $0 \%$ & $6 \%$ \\
\hline Wheat meal & 60 & 60 \\
Rapeseed meal & 18 & 18 \\
Wheat bran & 20 & 14 \\
Minerals & 2 & 2 \\
Fat & 0 & 6 \\
\hline
\end{tabular}




\section{Experiment 2}

Four lactating ewes of $50 \pm 5 \mathrm{~kg}$ body weight were assigned in a $4 \times 4$ Latin square design to four diets differing in supplemental fat source. Each experimental period was $16 \mathrm{~d}$ and consisted of 12 days of adjustment followed by 4 days of sample collection. Sheep had free access to water and were fed twice daily following each milking. The daily basic ration (control group) consisted of forage and concentrate (60:40) and was supplemented for experimental groups with 0, 4, 8 and $10 \%$ in dry matter of rape seed oil, linseed oil or hydrogenated rape seed oil. The concentrate consisted of wheat meal, soyabean meal, wheat bran and minerals (Table 2). The energy value of the rations was $1.21 \mathrm{JPM}$, whereas the crude protein content was $120 \mathrm{~g} \mathrm{BTJN}$ and $129 \mathrm{~g} \mathrm{BTJE}$. Sheep were milked twice daily at approximately 08.00 and 17.00 , and yields were recorded.

TABLE 2

Composition of the diet for eves (Experiment 2), \%

\begin{tabular}{lrrrr}
\hline Supplemented fat, $\%$ & 0 & 4 & 8 & 10 \\
\hline Meadow hay & 59.0 & 57.0 & 55.0 & 54.0 \\
Wheat meal & 21.0 & 20.0 & 19.0 & 19.0 \\
Rapeseed meal & 3.0 & 3.0 & 3.0 & 3.0 \\
Wheat bran & 15.0 & 14.0 & 13.0 & 12.0 \\
Minerals & 2.0 & 2.0 & 2.0 & 2.0 \\
Fat & 0.0 & 4.0 & 8.0 & 10.0 \\
\hline
\end{tabular}

Analysis

The level of conjugated linoleic acid in muscles (M. longissimus dorsi) of lamb and milk of ewes was determined according to the procedures of Heinig et al. (1998), modified by Czauderna et al. (2001). All data were analyzed using SAS procedures (User's Guide, 1990).

\section{RESULTS}

Feeding fat of vegetable origin to lambs had no significant influence on meat fat CLA content (Table 3). CLA content in milk increased $(\mathrm{P}<0.05)$ from $0.42 \mu \mathrm{g} / \mathrm{g}$ in the control group to $0.61,1.47$ and $2.72 \mu \mathrm{g} / \mathrm{g}$, respectively, in groups with 4,8 and $10 \%$ added linseed oil (Table 4 ). The addition of rape seed oil and hydrogenated rapeseed oil had no influence on CLA content. 
TABLE 3

Conjugated linoleic acid level in meat, $\mu \mathrm{g} / \mathrm{g}$

\begin{tabular}{|c|c|c|c|c|c|c|c|c|}
\hline \multirow[t]{2}{*}{ Meat } & \multicolumn{2}{|c|}{ Control } & \multicolumn{2}{|c|}{ Rape seed oil } & \multicolumn{2}{|c|}{ Linseed oil } & \multicolumn{2}{|c|}{$\begin{array}{l}\text { Hydrogenated } \\
\text { rape seed oil }\end{array}$} \\
\hline & mean & $\mathrm{CV}$ & mean & $\mathrm{CV}$ & mean & $\mathrm{CV}$ & mean & $\mathrm{CV}$ \\
\hline CLA & 0.02 & 34.40 & 0.03 & 30.98 & 0.03 & 29.96 & 0.03 & 209.08 \\
\hline
\end{tabular}

TABLE 4

Conjugated linoleic acid level in milk, $\mu \mathrm{g} / \mathrm{g}$ of lyophilized samples

\begin{tabular}{|c|c|c|c|c|c|c|c|c|}
\hline \multirow{2}{*}{$\begin{array}{l}\text { Supplemented } \\
\text { fat, } \%\end{array}$} & \multicolumn{2}{|c|}{0} & \multicolumn{2}{|c|}{4} & \multicolumn{2}{|c|}{8} & \multirow{2}{*}{$\frac{9}{\text { mean }}$} & \multirow{2}{*}{$\frac{10}{\mathrm{CV}}$} \\
\hline & mean & $\mathrm{CV}$ & mean & $\mathrm{CV}$ & mean & $\mathrm{CV}$ & & \\
\hline Rape seed oil & 1.26 & 39.02 & 1.21 & 59.97 & 1.32 & 64.00 & 1.34 & 58.71 \\
\hline Linseed oil & $0.42^{\mathrm{b}}$ & 40.40 & $0.61^{\mathrm{a}}$ & 58.63 & 1.47 & 103.06 & $2.72^{\mathrm{ab}}$ & 89.94 \\
\hline $\begin{array}{l}\text { Hydrogenated } \\
\text { rape seed oil }\end{array}$ & 1.58 & 58.82 & 1.28 & 64.06 & 1.53 & 48.98 & 1.15 & 89.39 \\
\hline
\end{tabular}

means in rows with the same letter differ statistically significant ${ }^{a, b . c}-\mathrm{P}<0.05$

\section{DISCUSSION}

Supplementation of diets for ruminants with fat changes the nutrient supply and composition of milk and meat (Romo et al., 2000). Literature data suggest that it may be possible to reduce the incidence of some cancers in humans by increasing the amount of CLA consumed in the diet. Potentially beneficial effects on body composition and on immune function have also been reported. Less consistent have been reports of putative hypocholesterolemic actions of CLA (Williams, 2000). Supplementing lamb diets with a source of linoleic acid seems to be a successful method of increasing the CLA content of tissues (Mir et al., 2000). In our experiment, adding fat did not significantly influence the CLA level in meat, though we observed a tendency for the CLA level to increase (by 50\%) but this was not significant $(\mathrm{P}>0.05)$ in lamb meat when the fat of rape seed oil, linseed oil or hydrogenated rape seed oil was added to the diets (Table 3 ). Because CLA is formed as an intermediate in the biohydrogenation of unsaturated fatty acids, hydrogenated rape seed oil, the source of most saturated fatty acids, had no influence on CLA content in either meat or in milk. Also rape seed oil added to sheep diets had no influence on CLA level in milk, whereas Mir et al. (1999) noted that feeding 4\% rape seed oil to dairy goats greatly increased milk fat CLA content (by 204\%). Experiments carried out by Desilets et al. (2000) indicate that regardless of the 
form of added canola (calcium salts of fatty acids from canola oil, free canola oil or whole ground canola seed) supplementing diets with canola increased milk CLA contents. Feeding linseed oil (a C18:3-rich oil) greatly increases milk fat CLA content (Chilliard et al., 2000) and is as at least as efficient as C18:2-rich vegetable oils. The obtained results indicate a significant correlation between adding linseed oil and the CLA level in milk. In our experiment, the addition of linseed oil also significantly $(\mathrm{P}<0.05)$ affected the CLA concentration.

An increased level of conjugated linoleic acid can be achieved by feeding optimal fat in a ruminant's ration. Further experiments are needed to determine the proper fatty acid composition of fat added to ruminant diets.

\section{REFERENCES}

Adlof R.O., Duval S., Emken E.A., 2000. Biosynthesis of conjugated linoleic acid in humans. Lipids $35,131-135$

Bessa R.J.B., Santos-Silva J., Ribeiro J.M.R., Portugal A.V., 2000. Reticulo-rumen biohydrogenation and the enrichment of ruminant edible products with linoleic acid conjugated isomers. Livest. Prod. Sci. 63, 201-211

Chilliard Y., Ferlay A., Mansbridge R.M., Doreau M., 2000. Ruminant milk fat plasticity: nutritional control of saturated, polyunsaturated, trans and conjugated fatty acids. Ann. Zootech. 49, 181205

Chouinard P.Y., Corneau L., Butler W.R., Chilliard Y., Drackley J.K., Bauman D.E., 2001. Effect of dietary lipid source on conjugated linoleic acid concentrations in milk fat. J. Dairy Sci. 84, 680690

Czauderna M., Kowalczyk J., Chojecki G., 2001. Separation of some mono-, di- and tri-unsaturated fatty acids containing eighteen carbon atoms by HPLC and photodiode array detection. J. Chromatogr. B (in press)

Desilets E., Pellerin D., Chouinard P.Y., 2000. Milk composition in Holstein cows fed canola oil in various forms. J. Anim. Sci. 78, Suppl. 1 /J. Dairy Sci. 83, Suppl. 1, 278 (Abstr.)

Heinig K., Hissner F., Martin S., Vogt C., 1998. Separation of saturated and unsaturated fatty acids by capillary electrophoresis and HPLC. Amer. Lab., May, 24-29

lp C., 1994. Conjugated linoleic acid in cancer prevention research: A report of current status and issues. Natl. Livest. Meat Board Res. Report No. 100 4, Chicago

Ip C., Scimeca J.A., Thompson H.J., 1994. Conjugated linoleic acid: A powerful anticarcinogen from animal fat sources. Cancer 74, 1051-1063

Mir Z., Goonewardene L.A., Okine E., Jaegar S., Scheer H.D., 1999. Effect of feeding canola oil on constituents, conjugated linoleic acid (CLA) and long chain fatty acids in goats milk. Small Ruminant Res. 33, 137-143

Mir Z., Rushfeldt M.L., Mir P.S., Paterson L.J., Weselake R.J., 2000. Effect of dietary supplementation with either conjugated linoleic acid (CLA) or linoleic acid rich oil on the CLA content of lamb tissues. Small Ruminant Res. 36, 25-31

Parodi P.W., 1994. Conjugated linoleic acid: An anticarcinogenic fatty acid present in milk fat. Aust. J. Dairy Technol. 49, 93-101 
Romo G.A., Erdman R.A., Teter B.B., Sampugna J., Casper D.P., 2000. Milk composition and apparent digestibilities of dietary fatty acids in lactating dairy cows abomasally infused with cis or trans fatty acids. J. Dairy Sci. 83, 2609-2619

SAS $^{\text {(i) }}$, 1990. SAS/STAT Users Guide (Release 6.03). SAS Institute Inc., Cary, NC (USA)

Williams C.M., 2000. Dietary fatty acids and human health. Ann. Zootech. 49, 165-180

\section{STRESZCZENIE}

Wplyw rodzaju i ilości dodanego do diety tluszczu na poziom sprzężonego kwasu linolowego w mięsie i mleku owcy

Sprzężony kwas linolowy (CLA) został ostatnio uznany jako potencjalny czynnik antykancerogenny, a jego jedynym naturalnym źródłem są produkty pochodzenia zwierzęcego. Celem przeprowadzonych doświadczeń było określenie wpływu dodatku oleju rzepakowego, oleju Inianego oraz uwodornionego oleju rzepakowego do dawki dla owiec na poziom sprzężonego kwasu linolowego w uzyskiwanym od nich mleku i mięsie. W pierwszym doświadczeniu 24 jagniąt o masie ciała $22 \pm 2 \mathrm{~kg}$ podzielono na 4 grupy i skarmiano dawkę kontrolną bez dodatku tłuszczu roślinnego, bądź z dodatkiem $6 \%$ oleju rzepakowego, oleju lnianego lub uwodorowanego oleju rzepakowego. W drugim doświadczeniu materiał doświadczalny stanowiły cztery owce mleczne o średniej masie ciała $50 \pm 5 \mathrm{~kg}$. Doświadczenie przeprowadzono w układzie kwadratu łacińskiego, $4 \times 4$. Zwierzęta żywiono dawkami z dodatkiem $0,4,8$ i $10 \%$ oleju rzepakowego, oleju lnianego lub uwodornionego oleju rzepakowego w suchej masie. Dodatek oleju rzepakowego oraz uwodornionego oleju rzepakowego nie mial wplywu na poziom CLA w mleku i w mięsie, natomiast olej Iniany dodany do dawki dla owiec podniósł statystycznie istotnie $(\mathrm{P}<0,05)$ poziom CLA w mleku. 